\title{
КАДРОВЫЙ ПОТЕНЦИАЛ РЕИНДУСТРИАЛИЗАЦИИ ТЕРРИТОРИЙ РОССИЙСКОЙ ФЕДЕРАЦИИ
}

\author{
(c) 2019 Данилов Иван Петрович \\ доктор экономических наук, \\ профессор кафедры государственного и муниципального управления и региональной экономики \\ Чувашский государственный университет, Россия, Чебоксары \\ E-mail: dip41@yandex.ru \\ (c) 2019 Морозова Наталия Витальевна \\ кандидат экономических наук, доцент, \\ зав. кафедрой государственного и муниципального управления и региональной экономики \\ Чувашский государственный университет, Россия, Чебоксары \\ E-mail:morozovanw@mail.ru \\ (c) 2019 Васильева Инесса Анатольевна \\ старший преподаватель \\ Чувашский государственный университет, Россия, Чебоксары \\ E-mail:inka107@mail.ru
}

В статье приведены основные результаты анализа кадрового потенциала реиндустриализации Российской Федерации. Настоящая работа является продолжением исследования теории и практики реиндустриализации, направленного на обеспечение повышение эффективности функционирования и конкурентоспособности российской экономики. Реализуемая в настоящее время в РФ экономическая политика не способствует реиндустриализации, поэтому необходимо уделить особое внимание факторам, которые непосредственно влияют на качество процесса реиндустриализации. Качественный кадровый потенциал региона способствует технико-технологическому обновлению и производству инновационной продукции, обеспечивает рост производительности труда и инновационной продукции.

Ключевые слова: реиндустриализация, кадровый потенциал, региональная политика, кадровая политика, индекс человеческого капитала, факторы реиндустриализации.

Представление о сущности кадрового потенциала определяет подход к его оценке, измерению и управлению. При оценке кадрового потенциала невозможно ограничиваться установлением количественных и качественных характеристик, а необходимо дополнительно анализировать данные, характеризующие интегральную оценку кадрового потенциала, учесть и выразить в показателях все факторы, оказывающие воздействие на развитие кадрового потенциала субъекта РФ.

Эксперты предлагают использовать всевозможные методы и подходы к оценке кадрового потенциала региона. В научной литературе имеются 4 группы оценки кадрового потенциала:

1. Методы оценки кадрового потенциала путем расчета совокупного объемного показателя. В данном случае в качестве совокупного объемного показателя специалисты предлагают ис- пользовать обобщающий потенциальный фонд рабочего времени.

2. Методика балльной оценки параметров кадрового потенциала. При данном методе каждый параметр кадрового потенциала определяется соответственными количественными показателями в определенных интервалах.

3. Метод оценки кадрового потенциала при помощи определенных стандартов. Этот метод образован с использованием балльной оценки, но дополняется ранжированием баллов внутри оценочной шкалы на группы с выделением оптимального, приемлемого, среднего и наихудшего диапазона значений.

4. Интегральная оценка кадрового потенциала. Данный метод предполагает объединение параметров, характеризующих кадровый потенциал с качественной и количественной сторон, в единый показатель. 
Интегральную оценку на основе конкретных показателей одним из первых предложил Генкин Б.М. Он ввел в научный оборот понятие индекса кадрового потенциала. На основе представленной им структуры параметров кадрового потенциала исследователь предлагает оценивать его применив следующую формулу:

ИКП $=f($ Инр $\cdot$ Изд $\cdot$ Иобр $\cdot$ Иак $\cdot$ Итв $\cdot$ Ипр $\cdot$ Иор $\cdot$ Ирв $)$,

где $И_{н р}-$ индекс нравственности;

$И_{3 д}$ - индекс здоровья;

$И_{\text {обр }}$ - индекс образования;

$И_{a \kappa}-$ индекс активности;

$h_{m в}-$ индекс творческого потенциала;

$И_{n p}-$ индекс профессионализма;

$И_{o p}$ - индекс организованности;

$И_{p в}-$ индекс ресурсов рабочего времени.

$f$ - функциональная зависимость параметров потенциала [1].

Для целей формирования развития и эффективного применения кадрового потенциала региона важным является не только уровень соотношения трудового потенциала региона, действительного уровня его применения и необходимого кадрового потенциала, но и выяснение причин несоответствия действительного и необходимого трудового потенциала, а также причин его недоиспользования.

Для сравнения уровня высококвалифицированных работников по субъектам Российской Федерации можно проанализировать следующие данные.

Анализ удельного веса численности высококвалифицированных работников в общей численности квалифицированных работников в регионе позволил сделать следующие выводы. Ни в одном субъекте РФ удельный вес высококвалифицированных работников не превышает $50 \%$, одной из причин такой ситуации в стране является трудовая иммиграция. Тем не менее, г. Москва $(49,1 \%)$ является лидером среди субъектов РФ. Наименьший показатель имеет Псковская область $-22,4 \%$

Профессиональное высшее образование должно соответствовать условиям социальноэкономического и научного развития. В 20162017 учебном году продолжалась развиваться система образования. Процесс модернизации направлен на повышение результативности деятельности организаций, которые осуществляют образовательную деятельность, усиление эффективности функционирования образова- тельной системы, в рамках которого происходило объединение образовательных организаций для того, чтобы оптимизировать бюджетные расходы на образование.

Анализ основных показателей, которые характеризуют систему высшего образования на территории Российской Федерации показал, что:

1) с 2005-2006 учебного года количество студентов очной формы обучения преобладает над количеством студентов заочной формы обучения. Например, в 2015-2016 учебном году по очной форме обучалось 2379,6 тысяч студентов, а по заочной форме обучения - 2237,8 тысяч студентов.

2) начиная с 2005-2006 учебного года, наблюдается сокращение численности студентов по всем формам обучения. Рассмотрим насколько снизился показатель по каждой форме обучения:

а) очная форма обучения:

$x=2379,6 * 100 \% / 3508=|67,8 \%-100 \%|=32,2 \%$. Таким образом, по состоянию на начало 20152016 учебного года количество студентов по очной форме обучения снизилось на $32,2 \%$ (или на 1128,4 тысяч студентов).

б) очно-заочная форма обучения:

$\mathrm{x}=149,1 * 100 \% / 371,2=|40,2 \%-100 \%|=59,8 \%$. Следовательно, число студентов по очно-заочной форме обучения с 2005-2006 учебного года снизилось на 59,8\% (или на 222,1 тысяч студентов).

в) заочная форма обучения:

$\mathrm{x}=2237,8 * 100 \% / 3032,0=|73,6 \%-100 \%|=26,3 \%$. Из этого следует, что показатель по заочной форме обучения снизился на 26,3\% (или на 794,2 тысяч студентов).

Стоит отметить, что наивысший показатель по сокращению количества студентов зафиксировано по очно-заочной форме обучения.

3) в свою очередь, отмечается и снижение числа высших образовательных учреждений: $\mathrm{x}=896 * 100 \% / 1068=|83,9 \%-100 \%|=16,1 \%$. Так, с начала исследуемого периода (2005-2006 учебный год) число высших образовательных учреждений сократилось на 16,1\% (или на 172 образовательных учреждений).

Как известно, демографическая ситуация в Российской Федерации до 2009 года имела отрицательную тенденцию. Такая обстановка в стране была связана со следующими проблемами:

1) сокращение численности населения; 
2) старение населения;

3) высокая смертность;

4) низкая рождаемость;

5) заболеваемость населения.

Для решения сложившейся ситуации государством предпринимались различные меры, вследствие чего демографическая обстановка в стране постепенно стала улучшаться.

Анализ численности населения позволил выявить следующее:

1) численность населения до 2009 года уменьшалась, и в 2009 году составила 142,7 млн. человек (самый низкий показатель в анализируемом периоде).

2) с 2009 года до 2013 года отмечается небольшой рост численности населения ( $\mathrm{x}=142,7^{*} 100 \% / 143,3=|99,6 \%-100 \%|=0,4 \%$ или на 0,6 млн. человек).

3) с 2013 года до 2016 года наблюдается резкое увеличение численности населения ( $\mathrm{x}=143,3 * 100 \% / 146,5=|97,8 \%-100 \%|=2,2 \%$ или на 3,2 млн. человек). В анализируемом периоде самый высокий показатель был в 2016 году - 146,5 млн. человек.

Немаловажную роль в определении кадрового потенциала играет численность и состав рабочей силы.

Значительная работа в направлении сохранения и развития кадрового потенциала общества ведется в рамках Программы развития $\mathrm{OOH}$ (ПРООН). Начиная с 1990 г. публикуются ежегодные «Доклады о развитии человека» по всем странам, а с 1995 г.- «Доклады о развитии человеческого потенциала в Российской Федерации». В этих документах в качестве количественного критерия принят индекс развития человеческого потенциала, который является существенно более объемным, чем традиционно использующиеся при оценках общего состояния той или иной страны экономические параметры. Этот индекс рассчитывается на основе трех показателей:

a) долголетия, измеряемого как ожидаемая продолжительность жизни при рождении и являющегося в принятой терминологии одним из признаков психофизиологического потенциала;

б) достигнутого уровня образования, отражающего позиции интеллектуального потенциала;

в) уровня жизни, измеряемого на базе реального валового внутреннего продукта на душу населения.
По индексу человеческого развития в Российской Федерации лидируют 2 города федерального значения (г. Москва 0,949, г. СанктПетербург 0,922). Основная часть субъектов РФ имеет значение ниже среднего $(0,875)$, что говорит о необходимости работы государственных органов в области содействия развития человеческого потенциала, который, бесспорно, влияет на уровень кадрового потенциала государства.

Очевидно, что полноценное обеспечение кадрами региональной экономики возможно в условиях тесного и целенаправленного взаимодействия систем образования, промышленного производства и государства. Налаживание трехстороннего межсекторного сотрудничества бизнеса, государства и институтов гражданского общества. Таким образом, проанализировав состояние показателей кадрового потенциала, можно сделать вывод, что значения данного показателя распределены по субъектам Российской Федерации неравномерно, что требует выравнивания, то есть проведения работы по развитию кадрового потенциала в более слабо развитых субъектах.

Таким образом, кадровая политика региона должна включать разработку принципов и механизмов востребованности кадрового потенциала региона. В ней находят отражение приоритеты регионального развития, выраженные в требованиях к содержанию и качеству работы служащих предприятий и организаций региона. Именно социально-ориентированная кадровая политика, направленная на обеспечение занятости всех граждан РФ играет огромную роль в развитии государства.

Рассмотрим показатели эффективности формирования и использования кадрового потенциала примере Чувашской Республики:

1) доля расходов на образование регионального бюджета в Чувашской Республике на 2017 год составляет 27,4\%. На статью «Образование» расходуется наибольшая часть бюджетных средств региона, что, несомненно, влияет на повышение уровня кадрового потенциала в регионе.

2) среднегодовая численность занятого населения региона и уровень его квалификации: основная доля занятых в регионе имеет среднее образование $(44,7 \%)$, далее высшее образование $(31,9 \%)$ и среднее образование $(20,2 \%)$; незначительные долю составляют занятые с основным общим $(3,2 \%)$ и не имеющие образования $(0,1 \%)$. 
Высокий уровень образованности занятых говорит об эффективности использования кадрового потенциала в Чувашской Республике.

Для сравнения ситуации уровня образования в разных регионах страны, проанализируем данные Росстата по численности студентов, обучающихся по программам подготовки квалифицированных рабочих, служащих за 2015 и 2016 года.

Самый низкий показатель по Российской Федерации как в 2015 году, так и в 2016 году 326 тысяч человек и 295 человек - отмечается в Северо-Западном федеральном округе в Ненецком автономном округе.

Самый высокий показатель по Российской Федерации как в 2015 году, так и в 2016 году 31720 тысяч человек и 27412 человек соответственно - отмечен в Приволжском федеральном округе в республике Башкортостан.

Далее рассмотрим ситуацию в 2016 году по федеральным округам Российской Федерации:

1) Центральный федеральный округ (104945 тысяч человек): самый низкий показатель в Калужской области - 2310 тысяч человек, самый высокий - Московская область - 16474 тысяч человек.

2) Северо-Западный федеральный округ (56402 тысяч человек): самый высокий г. Санкт-Петербург (17993 тысяч человек).

3) Южный федеральный округ (71862 тысяч человек): Ростовская область (21752 тысяч человек) лидирует по численности студентов, республика Калмыкия (1175 тыс. человек) в данном федеральном округе занимает последнее место.

4) Северо-Кавказский федеральный округ (29705 тысяч человек): лидеры по максимуму и минимуму - республика Дагестан (7484 тысяч человек), Карачаево-Черкесская республика (812 тысяч человек).

5) Приволжский федеральный округ (126394 тысяч человек): самую низкую позицию занимаетреспублика Марий Эл (2034 тысяч человек).

6) Уральский федеральный округ (50640 тысяч человек): лидирует по численности студентов Свердловская область (18506 тысяч человек), в Ямало-Ненецком автономном округе 2187 тысяч человек.

7) Сибирский федеральный округ (94335 тысяч человек): самый высокий показатель в Красноярском крае - 14685 тысяч человек, самый низкий показатель - республика Алтай
(999 тысяч человек).

8) Дальневосточный федеральный округ (28691 тысяч человек): лидирующее положение занимает Приморский край (7109 тысяч человек), минимальное значение в Еврейской автономной области (1020 тысяч человек).

Как в 2015, так и в 2016 году по доле студентов высшего образования лидирует Приволжский федеральный округ (156020 тысяч человек и 126394 тысяч человек соответственно). В 2015 году самый низкий показатель -35708 тысяч человек - отмечается в Северо-Кавказском федеральном округе, а в 2016 году - в ДальнеВосточном федеральном округе (28691 тысяч человек).

Численность студентов, обучающихся по программам подготовки квалифицированных рабочих, служащих в 2016 году заметно снизилась по сравнению с 2015 годом. Такая ситуация, прежде всего, характеризуется следующими причинами:

1) с начала 2011-2012 учебного года число российских вузов сократилось в 1,2 раза - с 1080 до 896 на начало 2015-2016 учебного года. Число государственных и частных вузов сократилось почти на 20\%. В марте 2015 года было объявлено, что количество вузов до 2020 года планируется уменьшить на $40 \%$, а число филиалов - на $80 \%$ [10].

2) низкое доверие россиян по отношению к отечественному образованию. Данные взгляды подтверждают места российских вузов в международных рейтингах.

Граждане России стараются получать высшее образование за границей. Количество студентов, обучающихся за рубежом, с каждым годом увеличивается. Например, в 2013 году за границей обучалось 50,6 тысяч российских студентов, а в 2015 году показатель достиг до 56,3 тысяч россиян ( $1 \%$ от общего числа российских студентов).

3) мнение населения о том, что высшее образование стало менее доступным, чем в СССР.

4) наблюдается сокращение бюджетных мест в ВУЗах РФ, по данным Росстата и Минобрнауки [11]:

Сокращение за 2000-2016 гг. составило 32\% (или сократилось на 893,5 тысяч мест). По данным министерства образования такая тенденция сохранится. В 2018 году планируется выделить 625 тысяч бюджетных мест. В 2019 году количество бюджетных мест по сравнению с 2018 годом будет меньше на 76 тысяч -549 ты- 
сяч мест. И только 312 тысяч бюджетных мест (57\% от общего количества бюджетных мест в 2019 году) выделится на программы бакалавриата.

Таким образом, для развития кадрового потенциала регионам следует:

1) обеспечить эффективную молодежную кадровую политику: повысить внимание к молодежи;

2) развивать и обучать персонал:

a) создать индивидуальную модель профессионального роста;

б) совершенствовать работу с кадровым резервом и молодыми специалистами;

в) формировать единую корпоративную культуру и ценности.

3) реализовать механизмы социального партнерства: формировать и совершенствовать инструменты согласования интересов корпорации и работников;

4) эффективно использовать персонал:

a) использовать экономические инструменты: система оплаты труда, мотивация и производительность труда;

б) формировать кадровый потенциал с использованием горизонтальной и вертикальной ротации персонала.

5) обеспечить достойную жизнь работникам и членам их семей:

а) развивать социальную инфраструктуру;

б) улучшить жилищные условия работникам и членам их семей.
6) совершенствовать систему мотивации и оплаты труда:

a) разработать несколько уровней компенсационных пакетов;

б) формировать мотивационные механизмы для закрепления высококвалифицированных кадров.

7) обеспечить адаптацию персонала к новой корпоративно среде: развивать отношения, формирующие высокие профессиональные и личностные качества работника.

8) содействие подготовке, обучению и переподготовке кадров в сфере инновационных технологий.

Из проведенной аналитической работы можно сделать вывод, что кадровый потенциал непосредственным образом влияет на развитие региона, государства и общества в целом. Поддержание развития системы подготовки и повышения квалификации кадров для инновационной деятельности, проведение непрерывного образования, начиная от общеобразовательных до профессиональных высших учебных заведений и постоянное повышение квалификации каждой личности в течение всей жизни - должно проводиться независимо от имеющегося уровня образовании в регионе. Только благодаря высококвалифицированным и опытным кадрам, а вследствие этого высокому уровню кадрового потенциала, возможно развитие современного государства.

Статья подготовлена при финансовой поддержке РФФИ в рамках научного проекта № 17-0200401-ОГН.

\section{Библиографический список}

1. Гайфулина М.М. Интегральный подход к оценке кадрового потенциала предприятия// Вестник ВЭГУ.2015.-4(78).- C. 22-33

2. Бузмакова М.В. Реиндустриализация - тенденция мировой экономики // Вестник Нижегородского университета им. Н.И. Лобачевского. - Серия: Социальные науки. - 2017. - № 1 (45).- С.7-17.

3. Методические положения оценки кадрового потенциала на региональном уровне [Электронный ресурс].Режим доступа: http://docplayer.ru/27677001-Metodicheskie-polozheniya-ocenki-kadrovogo-potenciala-naregionalnom-urovne.html

4. Костюченко А.П. Статистический анализ основных показателей системы высшего профессионального образования в России // Молодой ученый. - 2017. - № 22.- С. 172-176.

5. Абдумажидова А.А. Демографическая ситуация в Российской Федерации // Молодой ученый.- 2017.№ 3.- С. 289-292.

6. Труд и занятость в России. 2017: Стат.сб./Росстат - Т78 М., 2017. - 261 с.

7. Развитие кадрового потенциала региона и система профессионального образования в современной России [Электронный ресурс]. - Режим доступа: https://vestnik.igps.ru/wp-content/uploads/V44/21.pdf 
8. Пути развития кадрового потенциала [Электронный ресурс].- Режим доступа: https://studwood.ru/1089975/ menedzhment/zaklyuchenie

9. Оценивание кадрового потенциала региона в целях управления качеством образования [Электронный ресурс].- Режим доступа: http://elar.rsvpu.ru/bitstream/123456789/3428/1/nito_2015_132.pdf

10. Сокращение числа студентов и реорганизация вузов: российское образование за 2013-2018 гг. [Электронный ресурс].- Режим доступа: https://oblast45.ru/publication/12928/

11. Количество бюджетных мест в ВУЗах [Электронный ресурс].- Режим доступа: http://easyen.ru/news/ kolichestvo_bjudzhetnykh_mest_v_vuzakh_sokrashhaetsja/2017-07-27-1132 